\title{
PENGARUH EFEKTIVITAS PERATURAN SEKOLAHDAN FASILITAS BELAJAR TERHADAP MOTIVASI DAN DISIPLIN BELAJAR SERTA IMPLIKASINYA PADA HASIL BELAJAR SISWA PADA MATA PELAJARAN IPS (Survey pada SMP Negeri klasifikasi SSN di Kabupaten Bandung Barat)
}

\author{
Rika Indriani Sholihat \\ Guru SMP Negeri 5 Padalarang \\ Uminazla.khilfa@gmail.com
}

\begin{abstract}
ABSTRAK
Masalah yang menjadi kajian dari penelitian ini adalah mengenai hasil belajar siswa.Inti kajiannya difokuskan pada faktor-faktor yang mempengaruhi hasil belajar siswa meliputi efektivitas peraturan sekolah, fasilitas belajar, disiplin belajar, motivasi belajar.Berdasarkan hal tersebut, pokok masalah yang terungkap dalam penelitian ini adalah adakah pengaruh efektivitas peraturan sekolah, fasilitas belajar, disiplin belajar dan motivasi belajar terhadap hasil belajar siswa secara parsial maupun secara simultan. Metode penelitian yang digunakan adalah Explanatory Survey Method, dengan tehnik pengumpulan angket skala lima kategori Likert, terhadap 344 orang siswa Sekolah Menengah Pertama (SMP) Negeri yang berklasifikasi Sekolah Standar Nasional (SSN) di Kabupaten Bandung Barat. Tehnik pengolahan data yang digunakan adalah Model Analisis Jalur (Path Analysis Models).
\end{abstract}

Kata kunci: efektivitas peraturan sekolah, fasilitas belajar, disiplin belajar, motivasi belajar, hasil belajar.

\section{ABSTRACT}

Issues of study of this research is on student learning outcomes. The core study focused on factors that affect student learning outcomes include the effectiveness of school rules, learning, learning discipline, motivation to learn. Accordingly, the subject matter revealed in this study is there any influence the effectiveness of school rules, learning, learning discipline and motivation toward learning outcomes of students partially or simultaneously. The method used is Explanatory Survey Method, the technique of collecting five categories Likert scale questionnaire, to 344 students of Junior High School (SMP) are classified State Schools National Standard (SSN) in West Bandung regency. Data processing technique used is Path Analysis Model (Path Analysis Models).

Keywords: effectiveness of school rules, facilities study, discipline of learning, learning motivation, learning outcomes.

\section{PENDAHULUAN}

Kondisi pembelajaran di Sekolah Menengah Pertama Negeri (SMPN) klasifikasi Sekolah Standar Nasional (SSN) di Kabupaten Bandung Barat (KBB), khususnya pada pelajaran Ilmu Pengetahuan Sosial (IPS) ditemukan bahwa hasil belajar peserta didik pada mata pelajaran IPS kelas 8 di SMPN klasifikasi SSN di Kabupaten Bandung Barat masih sangat rendah.Hal ini menunjukkan bahwa pembelajaran IPS belum efektif pembelajaran yang menyebabkan rendahnya hasil belajar peserta didik dan menunjukan kualitas Proses Belajar Mengajar (PBM) masih belum maksimal menyebabkan masih rendahnya kualitas pendidikan yang dilakukan. Karena hasil belajar yang bermutu hanya bisa dicapai melalui proses belajar yang bermutu pula.

Ada beberapa faktor-faktor yang menyebabkan rendahnya hasil belajardi SMPN klasifikasi SSN di Kabupaten Bandung Baratdiduga disebabkan oleh rendahnya Efektivitas Peraturan Sekolah, fasilitas sekolah, disiplin belajar dan motivasi belajar. Menurut Abu Alimadi (2003:78) Ada beberapa faktor yangmenyebabkan rendahnya hasil belajar, di antaranya: faktor intern (faktor dari dalam diri manusia itu sendiri) dan faktor ekstern (faktor dari luar manusia)". Faktor- faktor intern meliputi faktor fisiologis, yaitu jasmani peserta didik dan faktor psikologis, yaitu disiplin belajar dan motivasi belajar, faktor 
eksternnya yaitu Efektivitas Peraturan Sekolah dan fasilitasbelajar.

Efektivitas peratuan sekolah sangat mendukungproses belajar, lingkungansekolah yang aman dan tertib dapat menumbuhkan semangat belajar peserta didik. Seperti yang dikemukakan oleh Rohiat (2011:67) "Lingkungan sekolah yang aman dan tertib, optimisme dan harapan atau ekspektasi yang tinggi dari warga sekolah, dan kegiatan yang terpusat pada peserta didik (student centered activities) adalah contoh-contoh iklim sekolah yang dapat menumbuhkan semangat belajar peserta didik". Efektivitas Peraturan Sekolah merupakan salah satu bentuk aturan yang harus ditaati dan dilaksanakan oleh peserta didik, sebagai satu perwujudan kehidupan yang sadar akan hukum dan aturan. Efektivitas Peraturan Sekolah adalah rambu-rambu kehidupan bagi peserta didik dalam melaksanakan kehidupan dalam masyarakat sekolah.Peserta didik yang memiliki sikap mentaati semua peraturan serta norma-norma yang ditetapkan dalam suatu situasi belajar, sehingga peserta dapat dengan tentram mengikuti belajar dan akan cenderung memperoleh hasil belajar yang maksimal. Sedangkan peserta didik yang tidak menaati peraturan dan norma-norma yang ditetapkan dalam situasi belajar akan cenderung mengalami kegagalan dalam proses belajar.

Menurut Winkel (Dianah, 2011:12), bahwa "hasil belajar itu sangat erat dengan usaha pembiasaan, sedangkan pembiasaan itu sendiri berhasil atau tidaknya tergantung pada kemampuan untuk menciptakan atau memegang teguh kedisiplinan. Jadi faktor kedisiplinan sangat besar pengaruhnya terhadap hasil belajar peserta didik".Menciptakan kedisiplinan peserta didik bertujuan untuk mendidik peserta didik agar sanggup memerintahkan diri sendiri. Mereka dilatih untuk dapat menguasai kemampuan, juga melatih peserta didik agar ia dapat mengatur dirinya sendiri, sehingga, para peserta didik dapat mengerti kelemahan atau kekurangan yang ada pada dirinya sendiri. Menanamkan disiplin kepada peserta didik merupakan tugas tenaga pengajar (guru). Untuk menanamkan kedisiplinan peserta didik harus dimulai dari dalam diri kita sendiri, barulah kita dapat menanamkan disiplin orang lain sehingga akan tercipta ketenangan, ketentraman, dan keharmonisan.

Motivasi juga bisa meningkatkan hasil belajar peserta didik. Proses belajar yang baik dan tepat akan menimbulkan motivasi belajar pada peserta didik, yang nantinya berdampak pada peningkatan hasil belajar peserta didik. Sejalan dengan yang dikemukakan oleh Gates (2000:56) bahwa motivasi adalah suatu kondisi fisiologis dan psikologis yang terdapat dalam diri seseorang yang mengatur tindakannya dengan cara tertentu.

Fasilitas belajar sangat penting dalam proses pembelajaran untuk mendukung kegiatan pengajaran dan juga dapat menimbulkan minat dan perhatian dari peserta didik untuk mempermudah penyampaian materi pembelajaran. Kegiatan belajar mengajar memerlukan adanya fasilitas agar kegiatan tersebut berjalan dengan lancar dan teratur.Pemenuhan fasilitas belajar yang baik dapat mendorong peserta didik untuk rajin belajar.

Permasalahan rendahnya hasil belajar begitu kompleks, rendahnya hasil belajar menunjukan rendahnya mutu pendidikan yang merupakan salah satu masalah yang terus-menerus dicari solusinya. Hal ini disebabkan karena hasil belajar peserta didik merupakan indikator tinggi rendahnya mutu pendidikan di suatu daerah. Tinggi rendahnya mutu pendidikan berhubungan erat dengan kualitas sumber daya manusia, sedangkan sumber daya manusia yang berkualitas tinggi mutlak dibutuhkan demi kemajuan suatu negara. Rangkaian hubungan tersebut menunjukkan bahwa penting bagi kita memberi perhatian penuh pada hasil belajar peserta didik jika dibiarkan begitu saja dapat menurunkan mutu Sumber Daya Manusia (SDM).

Penelitian ini penting dilakukan karena hasil penelitian ini dapat dijadikan dasar 
pengambilan kebijakan di bidang pendidikan khususnya dalam meningkatkan hasil belajar peserta didik. Diantara upaya untuk meningkatkan hasil belajar ini dapat dilakukan dengan meningkatkan disiplin belajar, motivasi belajar, fasilitas belajar dan efektifitas peraturan sekolah.

Pembahasan teoritis dan praktis di atas penting untuk diteliti terutama mengenai berbagai hal yang berkaitan dengan peningkatan disiplin, motivasi belajar, fasilitas belajar dan efektifitas peraturan sekolah dalam rangka meningkatkan hasil belajar peserta didik di sekolah dengan menggunakan metode kuantitatif.

Teori yang digunakan dalam penelitian ini adalah teori belajar konstruktivistik dari Glaserfeld, Bettencourt dan Piaget. Hasil belajar sebagai variabel dependen diduga dipengaruhi oleh faktor disiplin, motivasi fasilitas belajar dan efektivitas peraturan sekolah sebagai variabel independen.Variabel hasil belajar menggunakan teori hasil belajar menurut Briggs. Variabel efektivitas peraturan sekolah menurut Hurlock. Variabel disiplin menurut Moeliono dan Swim dkk . Variabel motivasi belajar menggunakan teori motivasi dari Maslow dalam Stoner dan freeman. Variabel fasilitas belajar menurut The Liang Gie dkk. Judul penelitian "Pengaruh efektivitas peraturan sekolah dan fasilitas belajar terhadap motivasi dan disiplin belajar serta implikasinya pada hasil belajar peserta didik mata pelajaran IPS" (Survey pada SMP Negeri klasifikasi SSN di Kabupaten Bandung Barat). Sistematika penulisan terdiri dari pendahuluan, metode penelitian, hasil dan pembahasan, kesimpulan.

\section{METODE PENELITIAN}

Metode penelitian merupakan langkah dan prosedur yang akan dilakukan untuk mengumpulkan data dalam rangka memecahkan masalah atau menguji hipotesis (Sujana, 1991:30). Cara ini dipergunakan setelah penyelidikan dengan memperhitungkan sewajarnya ditinjau dari tujuan penyelidikan dan situasi penyelidikan. (Arikunto, 2002 :126). Metode deskriptif yang digunakan dalam penelitian ini menggunakan metode survey, yaitu penelitian dengan mengajukan pertanyaan kepada subjek penelian kemudian menganalisis semua jawabannya.Survey dilakukan untuk melihat kondisi dan hubungan atau pengaruh variabel-variabel yang diteliti.

\section{HASIL DAN PEMBAHASAN}

Berdasarkan hasil analisis data penelitian yang dilakukan, secara garis besar dapat dianalisis bahwa efektivitas peraturan sekolah, fasilitas belajar, disiplin belajar, dan motivasi belajar berpengaruh terhadap hasil belajar peserta didik. Berikut ini akan dibahas secara komprehensif.

1. Pengaruh efektivitas peraturan sekolah terhadap disiplin belajar

Berdasarkan hasil uji korelasi pada penelitian ini terdapat korelasi antara efektivitas peraturan sekolah dengan disiplin belajar, hasil analisis path diperoleh koefisien path sebesar 0,520. Angka tersebut memiliki arti bahwa pengaruh Efektivitas Peraturan Sekolah terhadap disiplin belajar peserta didik SMP Negeri yang berklasifikasi SSN di Kabupaten Bandung Barat adalah sebesar $27 \%$ dan sisanya dipengaruhi oleh variabel lain.

Pengaruh sebesar $27 \%$ tersebut juga diperkuat dengan hasil uji nilai signifikansi yang di peroleh sebesar 0,00 yang nilainya lebih kecil dengan $\alpha=0,05(0,00<0,05)$, artinya efektivitas peraturan sekolah dan disiplin belajar memiliki hubungan yang signifikan.

Efektivitas peraturan sekolah dapat menjadi salah satu faktor yang mempengaruhi disiplin belajar peserta didik, dimana efektivitas peraturan sekolah adalah usaha sekolah untuk memelihara perilaku peserta didik agar tidak menyimpang dan dapat mendorong peserta didik untuk berperilaku disiplin sesuai dengan norma, peraturan dan tata tertib yang berlaku di sekolah. 
Ketika seorang peserta didikpatuh dan taat terhadap berbagai peraturan dan tata tertib yang berlaku di sekolahnya maka disiplin belajar peserta didik meningkat atau semakin baik. Penerapan Efektivitas Peraturan Sekolahjuga kadangkala diterapkan pula untuk memberikan hukuman (sanksi) sebagai konsekuensi dari pelanggaran terhadap peraturan.

Berkenaan dengan tujuan pendisiplinan dalam belajar dengan penegakan efektivitas peraturan sekolah, Maman Rachman (1999) mengemukakan bahwa tujuan efektivitas peraturan sekolah adalah: (1) Memberi dukungan bagi terciptanya perilaku yang tidak menyimpang; (2) Mendorong peserta didik melakukan yang baik dan benar; (3) Membantu peserta didik memahami dan menyesuaikan diri dengan tuntutan lingkungannya dan menjauhi hal-hal yang dilarang oleh sekolah; (4) Peserta didik belajar hidup dengan kebiasaan-kebiasaan yang baik dan bermanfaat baginya serta bagi lingkungannya.

Berdasarkan hasil penelitian di SMP Negeri di Kabupaten Bandung Barat diperoleh hasil bahwa efektivitas peraturan sekolah berpengaruh positif terhadap disiplin belajar peserta didik pada mata pelajaran Ilmu Pengetahuan Sosial (IPS) sebesar 11,8 \%, sisanya dipengaruhi variabel lain yang tidak diteliti. Artinya bahwa efektivitas peraturan sekolah yang dimiliki oleh setiap SMP Negeri di Kabupaten Bandung barat masih belum optimal. Hal ini dapat dilihat dari rata-rata 29,80 dari skor maksimal 46. Dengan tidak maksimalnya efektivitas peraturan sekolah di SMP Negeri di Kabupaten Bandung Barat, menjadi sebuah masukan bagi sekolah untuk meningkatkan efektifitas efektivitas peraturan sekolah dalam penerapannya di sekolah sekabupaten Bandung Barat. Dalam penetitian ini juga di peroleh bahwa disiplin belajar peserta didik dipengaruhi oleh variabel lain sebesar 73\% sebagaimana kita tahu bahwa disiplin belajar peserta didik tidak hanya di pengaruhi efektivitas peraturan sekolah melainkan oleh faktor-faktor yang lain seperti dijelaskan oleh M. Ngalim Purwanto (1995:
102) ada dua faktor yang mempengaruhi disiplin yaitu: Faktor individual atau faktor yang ada pada diri individu sendiri antara lain faktor kematangan, kesadaran, latihan, motivasi serta faktor pribadi dan faktor sosial atau faktor yang ada di luar diri individu antara lain faktor keluarga, keadaan rumah tangga, cara guru mengajar, alat-alat yang digunakan dalam belajar, lingkungan, kesempatan serta motivasi sosial.

\section{Pengaruh efektivitas peraturan sekolah terhadap motivasi belajar}

Berdasarkan hasil uji korelasi pada penelitian ini terdapat korelasi antara efektivitas peraturan sekolah dengan motivasi belajar, hasil analisis path diperoleh koefisien path sebesar 0,437. Angka tersebut memiliki arti bahwa pengaruh efektivitas peraturan sekolah terhadap motivasi belajar peserta didik SMP Negeri yang berklasifikasi SSN di Kabupaten Bandung Barat adalah sebesar $19,1 \%$ dan sisanya dipengaruhi oleh variabel lain.

Pengaruh sebesar 19,1\% tersebut juga diperkuat dengan hasil uji nilai signifikansi yang di peroleh sebesar 0,00 yang nilainya lebih kecil dengan $\alpha=0,05(0,00<0,05)$, artinya efektivitas peraturan sekolah dan motivasi belajar memiliki hubungan yang signifikan.

Efektivitas peraturan sekolah dapat menjadi salah satu faktor yang mempengaruhi motivasibelajar, dengan penerapan efektivitas peraturan sekolah yang bisa menciptakan situasi yang mendukung untuk proses belajar mengajar sehingga tercipta suasana yang tenang, tertib dan tentram sehingga bisa meningkatkan motivasi peserta didik dalam belajar. Berdasarkan hasil penelitian di SMP Negeri di Kabupaten Bandung Barat diperoleh hasil bahwa efektivitas peraturan sekolah berpengaruh positif terhadap motivasi belajar peserta didik pada mata pelajaran Ilmu Pengetahuan Sosial (IPS) sebesar 19,1\%, sisanya dipengaruhi variabel lain yang tidak diteliti. Artinya bahwa efektivitas peraturan sekolah yang dimiliki oleh setiap SMP Negeri di kabupaten bandung barat masih 
belum maksimal. Dengan tidak maksimalnya efektivitas peraturan sekolah di SMP Negeri di Kabupaten Bandung Barat, menjadi sebuah masukan bagi sekolah untuk meningkatkan efektivitas efektivitas peraturan sekolah dalam meningkatkan motivasi belajar belajar dalam penerapannya di sekolah se-kabupaten Bandung Barat.

\section{Pengaruh Fasilitas Belajar Terhadap Motivasi Belajar}

Berdasarkan hasil uji korelasi pada penelitian ini terdapat korelasi antara fasilitas belajar dengan motivasi belajar, hasil analisis path diperoleh koefisien path sebesar 0,278. Angka tersebut memiliki arti bahwa pengaruh fasilitas belajar terhadap motivasi belajar peserta didik SMP Negeri yang berklasifikasi SSN di Kabupaten Bandung Barat adalah sebesar $7,7 \%$ dan sisanya dipengaruhi oleh variabel lain.

Pengaruh sebesar $7,7 \%$ tersebut juga diperkuat dengan hasil uji nilai signifikansi yang di peroleh sebesar 0,00 yang nilainya lebih kecil dengan $\alpha=0,05(0,00<0,05)$, artinya fasilitas belajar dan motivasi belajar memiliki hubungan yang signifikan.Fasilitas belajar dapat menjadi salah satu faktor yang mempengaruhi motivasi belajar, dengan fasilitas belajar yang lengkap yang bisa mempermudah proses belajar mengajar bisa meningkatkan motivasi belajar peserta didik. Dengan fasilitas belajar yang lengkap membuat pembelajaran lebih menyenangkan tidak monoton sehingga bisa meningkatkan motivasi dalam belajar. Berdasarkan hasil penelitian di SMP Negeri di Kabupaten Bandung Barat diperoleh hasil bahwa fasilitas belajar berpengaruh positif terhadap motivasi belajar peserta didik pada mata pelajaran Ilmu Pengetahuan Sosial (IPS) sebesar 7,7\%, sisanya dipengaruhi variabel lain yang tidak diteliti. Artinya bahwa fasilitas belajar yang dimiliki oleh setiap SMP Negeri di kabupaten bandung barat masih belum lengkap. Dengan tidak lengkapnya fasilitas belajar di SMP Negeri di Kabupaten Bandung Barat, menjadi sebuah masukan bagi sekolah untuk meningkatkan pengadaan fasilitas belajar dalam meningkatkan motivasi belajar belajar dalam penerapannya di sekolah se-kabupaten Bandung Barat.

\section{Pengaruh disiplin belajar terhadap motivasi belajar}

Berdasarkan hasil uji korelasi pada penelitian ini terdapat korelasi antara disiplin belajar dengan motivasi belajar, hasil analisis path diperoleh koefisien path sebesar 0,083. Angka tersebut memiliki arti bahwa pengaruh disipiln belajar terhadap motivasi belajar peserta didik SMP Negeri yang berklasifikasi SSN di Kabupaten Bandung Barat adalah sebesar $0,69 \%$ dan sisanya dipengaruhi oleh variabel lain.

Pengaruh sebesar $0,69 \%$ tersebut juga diperkuat dengan hasil uji nilai signifikansi yang di peroleh sebesar 0,00 yang nilainya lebih kecil dengan $\alpha=0,05(0,00<0,05)$, artinya disiplin belajar dan motivasi belajar memiliki hubungan yang signifikan.

Secara umum menunjukkan bahwa motivasi belajar dan disiplin belajar merupakan faktor yang penting agar diperoleh hasil belajar yang optimal. Dengan adanya motivasi belajar dan diikuti disiplin belajar yang tinggi maka akan diperoleh hasil belajar yang tinggi pula, begitu juga dengan sebaliknya. Motivasi akan membentuk kesadaran dan disiplin belajar akan berpengaruh terhadap cara dan sikap belajar yang akhirnya akan diperoleh hasil belajar. Sedangkan disiplin belajar merupakan suatu bentuk kesadaran tindakan untuk belajar seperti disiplin mengikuti pelajaran, ketepatan dalam menyelesaikan tugas, kedisiplinan dalam mengikuti ujian, kedisiplinan dalam menepati jadwal belajar, kedisiplinan dalam mentaati tata tertib yang berpengaruh langsung terhadap cara dan teknik peserta didik dalam belajar yang hasilnya dapat dilihat dari prestasi belajar yang dicapai.Berdasarkan hasil penelitian di SMP Negeri di Kabupaten Bandung Barat diperoleh hasil bahwa disiplin belajar berpengaruh positif terhadap motivasi belajar peserta didik pada mata pelajaran Ilmu Pengetahuan Sosial (IPS) sebesar 0,69\%, sisanya dipengaruhi variabel lain yang tidak diteliti. Artinya bahwa disiplin belajar 
yang dimiliki oleh setiap SMP Negeri di Kabupaten Bandung Barat belum maksimal. Dengan tidak maksimalnya disiplin belajar di SMP Negeri di Kabupaten Bandung Barat, menjadi sebuah masukan bagi sekolah untuk meningkatkan disiplin belajar dalam rangka meningkatkan motivasi belajar peserta didik belajar dalam penerapannya di sekolah sekabupaten Bandung Barat.

\section{Pengaruh fasilitas belajar terhadap hasil} belajar

Berdasarkan hasil uji korelasi pada penelitian ini terdapat korelasi antara fasilitas belajar dengan hasil belajar, hasil analisis path diperoleh koefisien path sebesar 0,287. Angka tersebut memiliki arti bahwa pengaruh fasilitas belajar terhadap hasil belajar peserta didik SMP Negeri yang berklasifikasi SSN di Kabupaten Bandung Barat adalah sebesar $8,2 \%$ dan sisanya dipengaruhi oleh variabel lain.

Pengaruh sebesar 8,2\% tersebut juga diperkuat dengan hasil uji nilai signifikansi yang di peroleh sebesar 0,00 yang nilainya lebih kecil dengan $\alpha=0,05(0,00<0,05)$, artinya fasilitas belajar dan hasil belajar memiliki hubungan yang signifikan.Fasilitas belajar dapat menjadi salah satu faktor yang mempengaruhi hasil belajar. Dalam penelitian terdahulu dinyatakan bahwa fasilitas sekolah dapat mempengaruhi guru dan peserta didik dalam meraih sukses pada proses belajar mengajar. Fasilitas sekolah yang dapat mendukung proses belajar mengajar yaitu sarana perpustakaan yang bermutu dilihat dari buku-buku penunjang belajar yang tersedia, keadaan ruangan, kebersihan, dan bagaimana petugas perpustakaan dalam melayani peserta didik dan mutu media belajar dilihat dari media belajar tersebut layak atau tidak. Menurut Suwarma Al Muchtar (2008:46), bahwa "sarana strategi pembelajaran IPS lebih difokuskan pada aspek media dan alat bantu pendidikan". Hasil penelitian Suwarma Al Muchtar (2008), terungkap dilapangan bahwa "media dan alat bantu pembelajaran untuk strategi pembelajaran IPS baru terbatas pada media dan alat cetak seperti buku, gambar dan
peta".Media yang banyak digunakan adalah buku paket ditambah dengan buku anjuran yang mendapat rekomendasi dari pihak berwenang.

Fasilitas belajar yang mencakup buku paket/ pegangan, ruang belajar, meja dan kursi belajar, komputer, perlengkapan belajar dan penerangan yang cukup akan sangat membantu peserta didik dalam belajar. Paling tidak akan memperkecil kesulitan belajar. Hal ini terbukti dalam penelitian ini.Kelengkapan fasilitas belajar di sekolah yang menjadi sampel dalam kategori kurang lengkap. Dari hasil belajar 344peserta didik, 188peserta didik atau 54,65 \% memiliki hasil belajar di bawah KKM (kategori rendah). Hal ini didukung hasil penelitian yang menunjukan bahwa fasilitas belajar sebesar 70,64\% kategori kurang lengkap.

Kendala yang dihadapi peserta didik dalam memenuhi kelengkapan fasilitas belajar, yang ditemukan dalam penelitian adalah kurang memiliki perlengkapan belajar dan kurang tersedianya komputer. Perlengkapan belajar yang standar seperti: bolpoint, penggaris, penghapus, serutan, pensil, dll, sering dianggap tidak terlalu penting sehingga peserta didik saling meminjam dan akhirnya perlengkapan belajar tidak terpenuhi. Komputer adalah salah satu fasilitas belajar yang cukup mahal.Tidak semua peserta didik berasal dari keluarga kaya, sehingga tidak mungkin memaksakan diri untuk memnuhi semua fasilitas belajar.Mereka yang berasal dari keluarga sederhana tentu saja harus pandai menentukan mana fasilitas yang harus dipenuhi.

Fasilitas belajar sangat penting dan berpengaruh terhadap hasil belajar, oleh karena itu pihak sekolah harus membantu menyediakan fasilitas belajar yang memadai. Diharapkan setiap sekolah memiliki laboratorium komputer untuk membantu para peserta didik yang tidak memiliki fasilitas komputer di rumah.Para orang tua hendaknya menyediakan kelengkapan belajar dan mengingatkan putra putrinya untuk memelihara kelengkapan belajar tersebut. 
Berdasarkan hasil penelitian di SMP Negeri di Kabupaten Bandung Barat diperoleh hasil bahwa fasilitas belajar berpengaruh positif terhadap hasil belajar peserta didik pada mata pelajaran Ilmu Pengetahuan Sosial (IPS) sebesar $8,2 \%$, sisanya dipengaruhi variabel lain yang tidak diteliti. Artinya bahwa fasilitas belajar yang dimiliki oleh setiap SMP Negeri di Kabupaten Bandung Barat belum lengkap. Dengan belum lengkapnya fasilitas belajar di SMP Negeri di Kabupaten Bandung Barat, menjadi sebuah masukan bagi sekolah untuk meningkatkan fasilitas belajar dalam rangka meningkatkan hasil belajar peserta didik dalam penerapannya di sekolah se-kabupaten Bandung Barat.

6. Pengaruh disiplin belajar terhadap hasil belajar

Berdasarkan hasil uji korelasi pada penelitian ini terdapat korelasi antara disiplin belajar dengan hasil belajar, hasil analisis path diperoleh koefisien path sebesar 0,171. Angka tersebut memiliki arti bahwa pengaruh disiplin belajar terhadap hasil belajar peserta didik SMP Negeri yang berklasifikasi SSN di Kabupaten Bandung Barat adalah sebesar $2,9 \%$ dan sisanya dipengaruhi oleh variabel lain.

Pengaruh sebesar 2,9\% tersebut juga diperkuat dengan hasil uji nilai signifikansi yang di peroleh sebesar 0,00 yang nilainya lebih kecil dengan $\alpha=0,05(0,00<0,05)$, artinya disiplin belajar dan hasil belajar memiliki hubungan yang signifikan.

Dari hasil uji hipotesis menunjukan bahwa disiplin belajar berpengaruh secara positif dan signifikan terhadap hasil belajar peserta didik. Menurut Syaiful Bahri (2008:15), "salah satu yang mengantarkan peserta didik berhasil dalam belajar adalah disiplin". Senada dengan pendapat Tu'u Tulus (2004:37), bahwa "Disiplin merupakan jalan bagi peserta didik untuk sukses dalam belajar dan pada saat masuk dalam dunia kerja. Kesadaran pentingnya norma, aturan, kepatuhan dan ketaan merupakan prasyarat kesuksesan seseorang".

Disiplin yang baik adalah disiplin yang berawal dari diri sendiri, sebab penegakan disiplin yang berawal dari diri sendiri, berarti disiplin itu timbul atas kesadaran sendiri.Orang yang berhasil dalam belajar dan berkarya disebabkan mereka selalu menempatkan disiplin di atas semua tindakan dan perbuatan. Hal ini sesuai dengan pendapat Sulistiyowati (2001:3), "agar seorang peserta didik dapat belajar dengan baik maka ia harus bersikap disiplin, terutama dalam hal: disiplin dalam menepati jadwal pelajaran, disiplin dalam mengatasi godaan yang akan menunda kondisi fisik". Sedangkan menurut Imelda (2002:3), bahwa; "Individu yang memiliki kedisiplinan belajar di rumah akan menunjukan ciri sebagai berikut: memiliki waktu belajar yang teratur, belajar dengan menyicil (sedikit demi sedikit), menyelesaikan tugas pada waktunya, belajar dalam suasana yang mendukung".

Senada dengan pendapat di atas, Walgito (1981:127) menyatakan bahwa "sekalipun mempunyai rencana belajar yang baik, tanpa adanya kedisiplinan maka tidak akan berpengaruh terhadap prestasinya". Dari hasil penelitian menunjukan bahwa hasil belajar peserta didik dapat dipengaruhi oleh disiplin belajar sebesar 2,9\%. Hal ini dapat diterima, karena banyak faktor lain diluar penelitian ini yang dapat mempengaruhi hasil belajar di sekolah dan dirumah yang dibuat sendiri, mengatasi godaan yang akan menunda waktu belajar, persiapan belajar (menjaga kondisi fisik), disiplin terhadap diri, menyelesaikan tugas pada waktunya, belajar dengan menyicil, menunjukan sikap antusias dalam belajar, tidak melakukan hal-hal yang dilarang guru dan belajar secara kontinyu.

Peserta didik yang menyadari bahwa belajar merupakan suatu kebutuhan dan kewajiban, dengan sendirinya peserta didik akan belajar tanpa ada yang memaksa dan peserta didik tersebut cenderung akan memiliki disiplin belajar yang tinggi. Kedisiplinan belajar pada peserta didik akan ikut memberikan pengaruh terhadap hasil belajar yang dicapainya. Peserta didik yang memiliki disiplin belajar yang tinggi akan dapat belajar dengan baik, terarah dan teratur sehingga dimungkinkan 
akan mendapat hasil belajar yang baik pula. Hal ini terbukti dalam penelitian ini. Tingkat disiplin belajar disekolah yang menjadii sampel, beranda dalam kategori sedang.Dari hasil belajar 344peserta didik, 188peserta didik atau 54,65\% memiliki hasil belajar di bawah KKM (kategori rendah). Karenanya disiplin belajar tidak bisa diabaikan karena akan mempengaruhi hasil belajr. Dengan disiplin belajar, peserta didikakan mampu mengkondisikan dirinya untuk belajar dan dengan kedisiplinan memungkinkan peserta didik untuk mencapai hasil belajar yang memuaskan sesuai dengan harapan masyarakat.Kendala yang dihadapi dalam disiplin belajar, diantaranya adalah: 1) melakukan hal-hal yang dilarang guru yaitu mencotek pada saat ulangan. 2) mengatasi godaan yang akan menunda waktu belajar yaitu godaan mematikan HP saat belajar dan godaan bermain dengan teman sebelum belajar.

Berhubungan disiplin belajar sangan penting dan berpengaruh terhadap hasil belajar, maka pihak sekolah khususnya para guru dan para orang tua hendaknya sama-sama menanamkan kejujuran, mendorong peserta didik untuk percaya diri dan memberikan motivasi untuk belajar lebih giat dan teratur agar pada saat ulangan peserta didik merasa siap dan tidak mencotek. Menurut Syaiful Bahri (2008:15), "kunci sukses belajar adalah belajar dengan teratur, disiplin dan bersemangat, konsentrasi, pengaturan waktu, istirahat dan tidur".

Peserta didik diarahkan untuk belajar teratur. Belajar dengan teratur merupakan pedoman mutlak yang tidak bisa diabaikan oleh seseorang yang menuntut ilmu di sekolah. Dengan belajar teratur peserta didikakan menguasai bahan pelajaran. Penguasaan atas semua bahan pelajaran dituntut secara dini, tidak harus menunggunya sampai menjelang ulangan atau ujian.Belajar teratur di sekolah dapat dipastikan bahwa peserta didik memiliki catatan lengkap.Itulah sebabnya penting membiasakan diri dengan sikap teratur dalam segala hal, terutama yang menyangkut masalah keberhasilan belajar.
Sikap yang terbiasa teratur adalah cerminan pribadi terpuji.Kejernihan berpikir harus dipertahankan selama menuntut ilmu karena itu kiat yang utama dalam belajar.

Peserta didik diberikan motivasi oleh berbagai pihak, baik guru, orang tua maupun oleh lingkungan sekitarnya, sehingga disiplin belajar yang muncul adalah disiplin dari kesadaran, bukan paksaan, menurut Ali Imron (1996 dalam Eveline Siregar 2010:53), mengemukakan enam unsur atau faktor yang mempengaruhi motivasi, yaitu; (1) Citacita/aspirasi pembelajaran; (2) Kemampuan pembelajar; (3) Kondisi pembelajar; (4) Kondisi lingkungan pembelajar; (5) Unsurunsur dinamis belajar/pembelajaran; dan (6) Upaya guru dalam membelajarkan pembelajaran

Menurut Ali Imron (1996), ada empat upaya yang dapat dilakukan oleh guru untuk meningkatkan motivasi belajar, yaitu: (1) Mengoptimalkan penerapan prinsip-prinsip belajar; (2) Mengoptimalkan unsur-unsur dinamis pembelajaran; (3) Mengoptimalkan pemanfaatan upaya guru dalam membelajarkan pembelajar juga menjadi faktor yang mempengaruhi motivasi; dan (4) Mengembangkan aspirasi dalam belajar.

Jadi motivasi belajar yang diupayakan oleh guru dapat membantu peserta didik untuk meningkatkan disiplin belajar yang muncul dari diri peserta didik karena kesadaran, bukan karena paksaan.

Menurut Syaiful Bahri (2008:17). "Disiplin yang muncul karena kesadaran disebabkan seseorang menyadari bahwa hanya dengan disiplinlah didapat keteraturan dalam kehidupan, dengan disiplinlah orang lain mengaguminya". Jadi dalam belajar sangat diperlukan disiplin. Orang yang berhasil dalam belajar dan berkarya disebabkan mereka selalu menempatkan disiplin di atas semua tindakan dan perbuatan.Peserta didik harus mentaati dan melaksanakan jadwal belajar yang telah disusun sendiri dengan ikhlas dan penuh semangat.

Peserta didik dibantu untuk mengatasi godaan yang akan menunda waktu belajar, 
yaitu dengan cara: pertama, guru melarang peserta didik untuk mengaktifkan HP disaat proses belajar mengajar berlangsung dan orang tua terus mengingatkan putra-putrinya untuk mematikan HP pada saat akan belajar dirumah, dengan demikian peserta didik akan mendapatkan konsentrasi dalam belajar. Orang yang tidak dapat berkonsentrasi, pasti tidak akan berhasil menyimpan atau menguasai pembelajaran, karena itu peserta didik harus berusaha untuk mempertahankan konsentrasinya dalam belajar. Seseorang yang tidak dapat berkonsentrasi ketika belajar bukanlah tanpa sebab.Ada hal-hal lain yang ikut mempengaruhi lama pendeknya daya konsentrasi seseorang ketika sedang belajar. Menurut Abu Ahmad (1991 dalam Syaiful Bahri 2008:21), mengemukakan sebabsebab seseorang tidak dapat berkonsentrasi, antara lain: (a) Kurang minat terhadap mata pelajaran, mengakibatkan seseorang sukar mengerti isi pelajaran. Akhirnya pikiran melayang-layang pada hal lain; (b) Banyak urusan yang sering mengganggu perhatian, baik urusan luar maupun urusan pribadi; (c) Adanya gangguan-gangguan suara keras seperti radio, tape, TV, udara yang sangat panas, meja berantakan dan sebagainya; dan (d) Adanya gangguan kesehatan atau terlalu lelah.

Masih menurut Abu Ahmadi (1991), untuk mengatasi agar seseorang dapat mengembangkan kemampuan konsentrasinya yaitu: (a) Harus berminat terhadap mata pembelajaran; (b) Harus mempunyai ruang khusus untuk belajar; (c) Meja belajar hendaknya bersih dari segala benda yang tidak bersangkut paut dengan mata pelajaran yang sedang dipelajari; (c) Mampu menghilangkan urusan-urusan kecil yang selalu mengganggu pikiran sehingga pikiran terbebas dari ketegangan-ketegangan kecil yang selalu mengganggu; (d) Alat tulis dan kertas merupakan alat yang sangat berguna untuk membantu menciptakan konsentrasi. Bagian-bagian penting dalam buku dapat digaris bawahi; (e) Istirahat sebentar jika merasa jemu dan letih belajar agar pikiran jernih kembali; dan (f) Usahakan agar badan selalu sehat.
Kedua, orang tua selalu mengingatkan putraputrinya untuk belajar terlebih dahulu atau mengerjakan tugas-tugas dari guru, sebelum mereka bermain dengan teman-temannya, sampai anak terbiasa untuk belajar sebelum mereka bermain.

\section{Pengaruh motivasi belajar terhadap hasil belajar}

Berdasarkan hasil uji korelasi pada penelitian ini terdapat korelasi antara motivasi belajar dengan hasil belajar, hasil analisis path diperoleh koefisien path sebesar 0,343. Angka tersebut memiliki arti bahwa pengaruh motivasi belajar terhadap hasil belajar peserta didik SMP Negeri yang berklasifikasi SSN di Kabupaten Bandung Barat adalah sebesar $11,8 \%$ dan sisanya dipengaruhi oleh variabel lain.

Pengaruh sebesar $11,8 \%$ tersebut juga diperkuat dengan hasil uji nilai signifikansi yang di peroleh sebesar 0,00 yang nilainya lebih kecil dengan $\alpha=0,05(0,00<0,05)$, artinya motivasi belajar dan hasil belajar memiliki hubungan yang signifikan.

Dengan adanya motivasi, maka peserta didik akan terdorong untuk belajar mencapai sasaran dan tujuannya karena yakin dan sadar akan kebaikan, kepentingan dan manfaatnya. Bagi peserta didik, motivasi ini sangat penting karena dapat menggerakkan perilaku peserta didik kearah yang positif sehingga mampu menghadapi segala tuntutan, kesulitan serta menanggung resiko dalam studinya. Menurut M. Dalyono (1997: 235) motivasi dapat menentukan baik tidaknya dalam mencapai tujuan sehingga semakin besar motivasinya akan semakin besar kesuksesan belajarnya.

Motivasi sebagai faktor batin berfungsi menimbulkan, mendasari, dan mengarahkan perbuatan belajar. Seorang yang besar motivasinya akan giat berusaha, tampak gigih, tidak mau menyerah, serta giat membaca untuk meningkatkan prestasi serta memecahkan masalah yang dihadapinya. Sebaliknya mereka yang motivasinya rendah, tampak acuh tak acuh, mudah putus asa, perhatiannya tidak tertuju pada pelajaran yang akibatnya peserta didik akan mengalami 
kesulitan belajar. Motivasi menggerakkan individu mengarahkan tindakan serta memilih tujuan belajar yang dirasa paling berguna bagi kehidupan individu. Dengan mempelajari motivasi maka akan ditemukan mengapa individu berbuat sesuatu. Motivasi individu tidak dapat diamati secara langsung, sedangkan yang dapat diamati adalah manifestasi dari motivasi itu dalam bentuk tingkah laku yang nampak pada individu setidaknya akan mendekati kebenaran apa yang menjadi motivasi individu yang bersangkutan.

\section{KESIMPULAN}

Berdasarkan hasil penelitian yang telah dilakukan dapat ditarik kesimpulan sebagai berikut:

1. Efektivitas Peraturan Sekolah di SMP negeri yang berklasifikasi SSN di kabupaten Bandung Barat termasuk kategori kurang efektif. Fasilitas belajar di SMP negeri yang berklasifikasi SSN di kabupaten Bandung Barat termasuk kategori tidak lengkap. Disiplin belajar di SMP negeri yang berklasifikasi SSN di kabupaten Bandung Barat termasuk kategori sedang. Motivasi belajar di SMP negeri yang berklasifikasi SSN di kabupaten Bandung Barat termasuk kategori sedang. Hasil belajar di SMP negeri yang berklasifikasi SSN di kabupaten Bandung Barat termasuk kategori rendah.

2. Terdapat pengaruh Efektivitas Peraturan Sekolah terhadap disiplin belajar di SMP negeri yang berklasifikasi SSN di kabupaten Bandung Barat. Artinya semakin efektif Efektivitas Peraturan Sekolah maka semakin tinggi disiplin belajar peserta didik.

3. Terdapat pengaruh Efektivitas Peraturan Sekolah terhadap motivasi belajar di SMP negeri yang berklasifikasi SSN di kabupaten Bandung Barat. Artinya semakin efektif Efektivitas Peraturan Sekolah maka semakin tinggi motivasi belajar peserta didik.
4. Terdapat pengaruh fasilitas belajar terhadap motivasi belajar di SMP negeri yang berklasifikasi SSN di kabupaten Bandung Barat. Artinya semakin lengkap fasilitas belajar maka semakin tinggi motivasi belajar peserta didik.

5. Terdapat pengaruh disiplin belajar terhadap motivasi belajar di SMP negeri yang berklasifikasi SSN di kabupaten Bandung Barat. Artinya semakin tinggi disiplin belajar maka semakin tinggi motivasi belajar peserta didik.

6. Terdapat pengaruh fasilitas belajar terhadap hasil belajar di SMP negeri yang berklasifikasi SSN di kabupaten Bandung Barat. Artinya semakin lengkap fasilitas belajar maka meningkatkan hasil belajar peserta didik.

7. Terdapat pengaruh disiplin belajar terhadap hasil belajar di SMP negeri yang berklasifikasi SSN di kabupaten Bandung Barat. Artinya semakin tinggi disiplin belajar maka meningkatkan hasil belajar peserta didik.

8. Terdapat pengaruh motivasi belajar terhadap hasil belajar di SMP negeri yang berklasifikasi SSN di kabupaten Bandung Barat. Artinya semakin tinggi motivasi belajar maka meningkatkan hasil belajar peserta didik.

\section{DAFTAR PUSTAKA}

Al Muchtar, S. (2008). Strategi Pembelajaran Pendidikan IPS. Bandung: Sekolah Pascasarjana Universitas Pendidikan Indonesia.

Alma, B. (2010). Pembelajaran Studisosial. Bandung: Alfabeta.

Arikunto, S. (2003).Dasar-dasar Evaluasi Pendidikan. Jakarta : Bumi Aksara.

Cahyono, H. (2009). Pengaruh Fasilitas Sekolah dan Motivasi Guru Terhadap efektifitas Proses Belajar Mengajar di SMK Negeri Garut. (Tesis). Bandung. Universitas Pendidikan Indonesia.

Dalyono.(1997). Psikologi Pendidikan. Jakarta: Rineka Cipta. 
Depdikbud.(2001). Kamus Besar Bahasa Indonesia. Jakarta : PN Persero Balaai Pustaka.

Dimyati dan Mudjiono.(1999). Belajar dan Pembelajaran.Jakarta : Rianeka Cipta.

Khodijah.(2006). Psikologi Balajar.Palembang : IAIN Raden Fatah Press.

Krismanto, H. (2007). Hubungan Kesiapan Fasilitas Belajar Layanan Pembelajaran dan Pengalaman Industri dengan Prestasi Balajar Mahapeserta didik di Politeknik TEDC Bandung.(Tesis). Bandung: Universitas Pendidikan Indonesia

Logayah. (2010). Hubungan antara Persepsi Kompetensi Profesionalisme Guru dan Minat Peserta didik dengan Keterampilan Georafis (Geographic Skills) di SMA Kota Bandung. (Tesis). Bandung: Universitas Pendidikan Indonesia

Mardiana.(2007). Pengaruh Kesiapan Guru, Fasilitas Sekolah dan Upaya Sekolah Terhadap efektifitas Implementasi Pembelajaran Berbasis Kerja di Sekolah Menengah Kejuruan.(Tesis). Bandung: Universitas Pendidikan Indonesia

Muslim. (2007). Hubungan Antara latar Belakang Pendidikan Guru, Fasilitas Pembelajaran dan Strategi Promosi dengan Efektifitas Pembelajaran berbasis Unit Produksi. Bandung: Universitas Pendidikan Indonesia

Purwanto.(2009). Evaluasi Hasil Belajar. Yogyakarta: Pustaka Pelajar

Riduwan dan Kuncoro, E. (2008). Cara Menggunakan dan Memaknai Analisis Jalur (Path Analisys). Bandung: Alfabeta.

Santoso, S. (2001).Buku Latihan SPSS Statistik Parametrik. Jakarta: PT. Elek Media Komputindo

Singarimbun, M. (1987).Metoda Penelitian Survai. Jakarta : LP3ES.

Singarimbun, M. (2008).Metoda Penelitian Survai. Jakarta : LP3ES.

Siregar, E. (2010). Teori Belajar dan Pembelajaran. Bogor : Ghalia Indonesia

Sirnam.(2008). Disiplin dan Harga Diri. Jakarta: PT. Indeks.

Somantri, M. (2001).Menggagas Pendidikan Pembaharuan Pendidikan IPS. Bandung: PT. Remaja Rosdakarya.

Sudjana, N. (2004). Penelitian Penilaian Pendidikan. Bandung: Sinar baru
Sugiyono.(2009). Metoda Penelitian Pendidikan; Pendekatan Kuantitatif, Kualitattif. Bandung: Alfabeta.

Sulistiyowati.(2008). Pengaruh Kedisiplinan Peserta didik dan Iklim Sekolah Terhadap Prestassi belajar Peserta didik Kelas II SMK Negeri 5 Semarang.www.wordpress.co, diakses tanggal 28 Februari 2013.

Suryabrata, S. (2010).Psikologi Pendidikan. Jakarta: PT Raja Grafindo Persada.

Tarmizi.(2008). Kedisiplinan Peserta didik di Sekolah. (online). Tersedia: http:/tarmizi.wordpress. com/2008/12/12/kedisiplinan-peserta didik-di-sekolah. (28 Februari 2013).

Tu'u, Tulus. (2004). Peran Disiplin Pada Perilaku dan Prestasi Peserta didik. Jakarta: Grasindo

W.S. Winkel. (1987). Psikologi Pendidikan dan evaluasi Balajar. Jakarta: Gramedia.

Wotto.(2000). Manajemen Peralatan Praktek. Yogyakarta: Gajah Mada University Press

Yusuf, S. (1989).Disiplin diri dalam Belajar Dihubungkan dengan Penanaman Disiplin yang Dilakaukan Orang Tua dan Guru. (Tesisi). Bandung: Institut Keguruan dan Ilmu Pendidikan. 